\title{
UV IDENTIFICATION SUBSTITUTION POSITION OF PYRIMIDINE RING
}

\section{ZASTOSOWANIE SPEKTROSKOPII UV W IDENTYFIKACJI POŁOŻENIA PODSTAWNIKÓW W PIERŚCIENIU PIRYMIDYNOWYM}

Department of Biochemistry Nicolaus Copernicus University in Toruń, Collegium Medicum in Bydgoszcz

S u m m a r y

Pyrimidine is six-member heterocyclic compound that contains two nitrogen atoms at positions 1 and 3. Pyrimidine derivatives have showed various biological activities such as antimicrobial, antitumor, antifungal, the hypnotic and sedative activities. The oxopyrimidnes of the biological activity of the most possess substituents at the $N 1$ or $N 3$ position [1-11].

This paper presents identification the location of the $N 1$ and $N 3$ isomeric substituents of the pyrimidine derivatives. The UV spectroscopy was used for this purpose. This method is simple, economical and does not require large quantities of sample.

The absorption maxima of the 1 and 3 -substituted pyrimidine derivatives were sensitive to the addition of base.
In alkaline solution the $N 3$-alkyl substituted uracil showed bathochromic shift, but the absorption maxima of $N 1$ analogs shift toward shorter wavelengths (the hypsochromic shift) (Figure 1, 2, 3). This was associated with the formation of monoanion, which was created as a result of dissociation of a proton from the nitrogen atom (Scheme 2).

The results were compared with the results that may be obtained from the analysis of proton nuclear magnetic resonance ${ }^{1} \mathrm{H}$ NMR (Scheme 1, 3, 4). The NMR spectroscopy is a method much more precise and it can provide more information about the structure of the compound. By ${ }^{1} \mathrm{H}$ NMR is not always possible clearly distinguish between $N 1$ and $N 3$ isomers, in contrast to the UV spectroscopy.

\section{Streszczenie}

Pirymidyna jest jednopierścieniowym, sześcioczłonowym heterocyklicznym związkiem aromatycznym zawierającym dwa atomy azotu w pozycji 1 i 3 . Jej pochodne zawierające podstawniki w pozycji $N 1$ i $N 3$ wykazują aktywność biologiczną i znajdują zastosowanie jako środki przeciwbakteryjne, przeciwgrzybicze, przeciwnowotworowe oraz uspokajające i nasenne [1-11].

W pracy została przedstawiona identyfikacja położenia podstawników w izomerycznych $N 1$ i $N 3$ pochodnych pirymidynowych. Do tego celu wykorzystano prostą, ekonomiczną, niewymagającą dużych ilości próbki metodę spektroskopię UV. Wykonane w środowisku zasadowym widma UV pochodnych $N 1$ podstawionych pochodnych uracylu wykazują charakterystyczne przesunięcie hipsochromowe maksimum absorbancji w stosunku do widma wykonanego $\mathrm{w} \mathrm{pH}=7$ (rys. 1, 2, 3). Efekt ten jest spowodowany powstawaniem monoanionu przez dysocjację protonu $\mathrm{z}$ azotu
N3 (schemat 2). Natomiast dysocjacja protonu z azotu $N 1$ w N3 podstawionych pochodnych uracylu prowadzi do powstania monoanionu $\mathrm{z}$ układem o znacznie silniejszym sprzężeniu (schemat 2). Wykonane w środowisku zasadowym widma UV tych związków wykazują charakterystyczne przesunięcie maksimum absorbancji w kierunku dłuższych fal - efekt batochromowy (rys. 1, 2, 3).

Uzyskane wyniki zostały porównane $\mathrm{z}$ wynikami analizy widma protonowego rezonansu jądrowego $\left({ }^{1} \mathrm{H}\right.$ NMR) (schemat 1, 3, 4). Spektroskopia NMR jest metodą znacznie bardziej dokładną. Można dzięki niej uzyskać więcej informacji o strukturze chemicznej badanego związku. Niestety, specyfika metody nie zawsze pozwala na rozróżnienie izomerycznych pochodnych $N 1$ i $N 3$ pirymidyny. Natomiast analiza widma UV pozwala w każdym przypadku w sposób jednoznaczny określić położenie podstawnika w pierścieniu pirymidynowym.

Key words: UV and ${ }^{1} \mathrm{H}$ NMR spectroscopy, $N 1$ and $N 3$-alkyl substituted uracil, bathochromic shift, hypsochromic shift 
Stowa kluczowe: spektroskopia UV i ${ }^{1} \mathrm{H}$ NMR, $N 1$ i $N 3$-alkilowe pochodne uracylu, efekt batochromowy, efekt hipsochromowy

\section{INTRODUCTION}

The pyrimidine nucleus has a key feature in various derivatives that are used as drugs. A number of pyrimidine bases have been shown to possess antiviral and anticancer activities [1-6], particularly uracils possessing halogens at the 5-position e.g. 5fluorouracil, 5-iodouracil and their $N 1$ and $N 3$ analogs [7-9]. The oxopyrimidnes such as $N 1, N 3$-disubstituted uracils were reported to exhibit antibacterial and antifungal activities [10] the hypnotic and sedative activities [11].

This paper presents how one can distinguish between $N 1$ and $N 3$ uracils derivatives using UV spectroscopy. This method is compared with nuclear magnetic resonance (NMR).

\section{EXPERIMENTAL SECTION}

\section{MATERIAL AND METHODS}

The chemical for synthesis of all compounds were from the POCH Chemical Company and used without further purification. The solvents were spectroscopic grade. ${ }^{1} \mathrm{H}$ NMR spectra were recorded on Bruker apparatus (TMS as an internal standard) in $\mathrm{CDCl}_{3}$. Chemical shift are expressed in $\delta$ unit (ppm). Ultraviolet-visible (UV-Vis) absorption spectra were recorded on Aqurius 7250 spectrophotometer (Cecil).

Table I. The molar extinction coefficients of derivatives of pyrimidine

Tabela I. Molowe współczynniki ekstynkcji pochodnych pirymidynowych

\begin{tabular}{|c|c|c|c|c|c|c|}
\hline \multirow[b]{3}{*}{$\begin{array}{c}\text { ZWIĄZKI } \\
\text { COUMPOND }\end{array}$} & \multicolumn{6}{|c|}{$\mathbf{U V}$} \\
\hline & \multicolumn{2}{|c|}{$\mathrm{pH}=2$} & \multicolumn{2}{|c|}{$\mathrm{pH}=7$} & \multicolumn{2}{|c|}{$\mathrm{pH}=12$} \\
\hline & 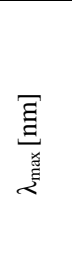 & 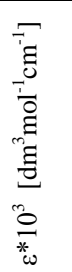 & 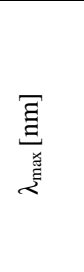 & 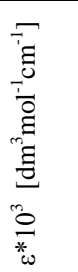 & 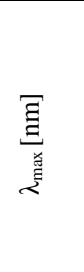 & 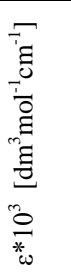 \\
\hline 1 & 270 & 3.048 & 270 & 3.048 & 269 & 3.458 \\
\hline 2 & 283.5 & 5.077 & 283.5 & 5.077 & 315 & 4.821 \\
\hline 3 & 272.5 & 2.868 & 272.5 & 3.000 & 269 & 2.363 \\
\hline 4 & 264 & 2.946 & 264.5 & 2.875 & 289 & 4.024 \\
\hline 5 & 273.5 & 3.408 & 273.5 & 3.379 & 271.5 & 2.689 \\
\hline 6 & 268.5 & 2.675 & 268 & 2.835 & 289 & 3.277 \\
\hline
\end{tabular}

A change of $\lambda_{\max }$ was investigated when $1 \mathrm{~mL}$ base $\left(\mathrm{NaOH}, 3 \times 10^{3} \mathrm{~mol} / \mathrm{dm}^{3}\right)$ or $1 \mathrm{~mL}$ acid $\left(\mathrm{HCl}, 3 \times 10^{3}\right.$ $\mathrm{mol} / \mathrm{dm}^{3}$ ) was added to $250 \mu \mathrm{l}$ the solution of samples $\left(0.001 \mathrm{~mol} / \mathrm{dm}^{3}\right.$ in ethanol) and $1750 \mu \mathrm{l}$ distilled water.

Compounds 1-6 were obtained according to literature procedure [12-14]. The molar extinction coefficients and $\lambda_{\max }$ are shown in the table I.

\section{RESULTS AND DISCUSSION}

The results obtained from the ${ }^{1} \mathrm{H}$ NMR and UV spectrum to determine the position of the substituents on the uracil derivatives were compared. The structure and the chemical shifts for 1-allyl- and 3-allyl-2tiouracil are shown below (Scheme 1).

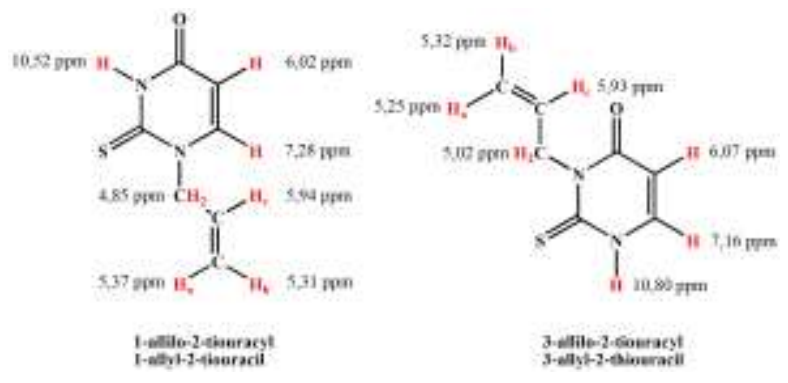

Scheme 1. The proton chemical shifts of 1-allyl-2-thiouracil and 3-allyl-2-thiouracil

Schemat. 1. Przesunięcia chemiczne protonów 1-allilo-2tiouracylu i 3-allilo-2-tiouracyl

On the basis of chemical shift in ${ }^{1} \mathrm{H}$ NMR spectrum cannot be concluded at which the nitrogen atom is located the allyl substituent. More information enabling the identification the $N 1$ (1) and $N 3$ of the 2thiouracil (2) can be deduced on the basis of spin-spin coupling. The protons C-5 and C-6 of the pyrimidine ring are of particular interest.

In the case of 3-allyl-2-thiouracil, the signal for the $\mathrm{C}-5-\mathrm{H}$ appears in the spectrum as a four peaks. The signal for $\mathrm{C}-5-\mathrm{H}$ is split into a doublet due to $\mathrm{C}-6-\mathrm{H}$ with the coupling constant $\mathrm{J}_{\mathrm{C} 5-\mathrm{C} 6}(7.6 \mathrm{~Hz})$, and this doublet is split into a doublet of doublets by $N 1-\mathrm{H}$ with the small coupling constant $\mathrm{J}_{\mathrm{C} 5-N 1}(1.2 \mathrm{~Hz})$. Similarly, the proton signal of C-6 is split into a doublet of doublets with the coupling constant $\mathrm{J}_{\mathrm{C} 5-\mathrm{C} 6} 7,6 \mathrm{~Hz}$, and the much larger coupling constant $\mathbf{J}_{\mathrm{C} 5-\mathrm{N} 1} 5,8 \mathrm{~Hz}$. Both coupling constants have a relatively large value (shortrange coupling), because the $\mathrm{C}-5-\mathrm{H}$ and the $\mathrm{N} 1-\mathrm{H}$ are in close vicinity of $\mathrm{C}-6-\mathrm{H}$. Hence the nitrogen atom at position $N 1$ is not substituted. The analysis of the ${ }^{1} \mathrm{H}$ NMR spectra can unequivocally state that it is 3-allyl2-thiouracil. 
The signal C-5-H of 1-allyl-2-tiouracil splits a doubled doublet. Next to the short-range coupling constant $\mathrm{J}_{\mathrm{C} 5-\mathrm{C} 6}(8.0 \mathrm{~Hz})$ of the $\mathrm{C}-6-\mathrm{H}$, can be read from the spectrum of the additional coupling constant $(2,1$ $\mathrm{Hz}$ ) of the $N 3-\mathrm{H}$ (long-range coupling). By contrast, the signal of C-6-H is split only into a doublet with the same coupling constant $\mathrm{J}_{\mathrm{C} 5-\mathrm{C} 6} 8.0 \mathrm{~Hz}$. There is no coupling constant $\mathrm{J}_{\mathrm{C} 5-\mathrm{N} 3}$, which shows the lack of a proton at $N 1$. This clearly indicates that the $N 1$ is substituted with the allyl group.

The position of the allyl in 2-thiouracil can be confirmed by performing the UV absorption spectrum. The absorption maxima of the 1 and 3-substituted pyrimidine derivatives were sensitive to the addition of base. The absorption spectra in an alkaline medium for the various 1-substituted uracil show that there is a general tendency for the absorption band to move (1-3 $\mathrm{nm}$ ) hypsochromically (band shift towards shorter wavelengths). However, in the 3-substituted analogs of pyrimidine bases bathochromic shift $(30 \mathrm{~nm})$ can be observed which is characteristic for the compounds of the absorption band shift toward longer wavelengths. This change in the spectrum is explained by the transformation of the substance into monoanion-form. In an alkaline environment free protons at the nitrogen atoms dissociate in both the 1 and 3 -substituted uracil. The dissociation constant for these weak acid is practically the same and is about $\mathrm{pK}=11$. The structure of monoanions shown in the scheme 2 .<smiles>[R2]c1[nH]c(=O)n([R1])c(=O)c1[R]</smiles><smiles>[R4]c1c([R3])n([R1])c(=O)[nH]c1=O</smiles>

Scheme. 2. The monoanions N1 and N3 of the pyrimidine derivatives

Schemat. 2. Monoaniony N1 i N3 pochodnych pirymidynowych

On the basis of UV spectra can be assigned the position of the allyl group at 1 and 3-substituted pyrimidine derivatives. In an alkaline medium $(\mathrm{pH}=$ 12) had a characteristic slightly hypsochromic shift for the $N 1$ derivative and a significant bathochromic shift 3 -substituted 2-thiouracil. The absorption band of 1allyl-2-thiouracil was at $268 \mathrm{~nm}\left(\Delta \lambda_{\max }=2 \mathrm{~nm}\right)$. In contrast, for the $N 3$ analog showing the absorption band shift toward longer wavelengths with an absorption maximum at $315 \mathrm{~nm}\left(\Delta \lambda_{\max }=30 \mathrm{~nm}\right)$. The value of the molar extinction coefficient for the derivative at the $\mathrm{pH}=12$ is lower than at the $\mathrm{pH}=4$ and $\mathrm{pH}=7$. The absorption spectra of compounds $\mathbf{1}$ and $\mathbf{2}$ in various $\mathrm{pH}$ are shown in figure 1.
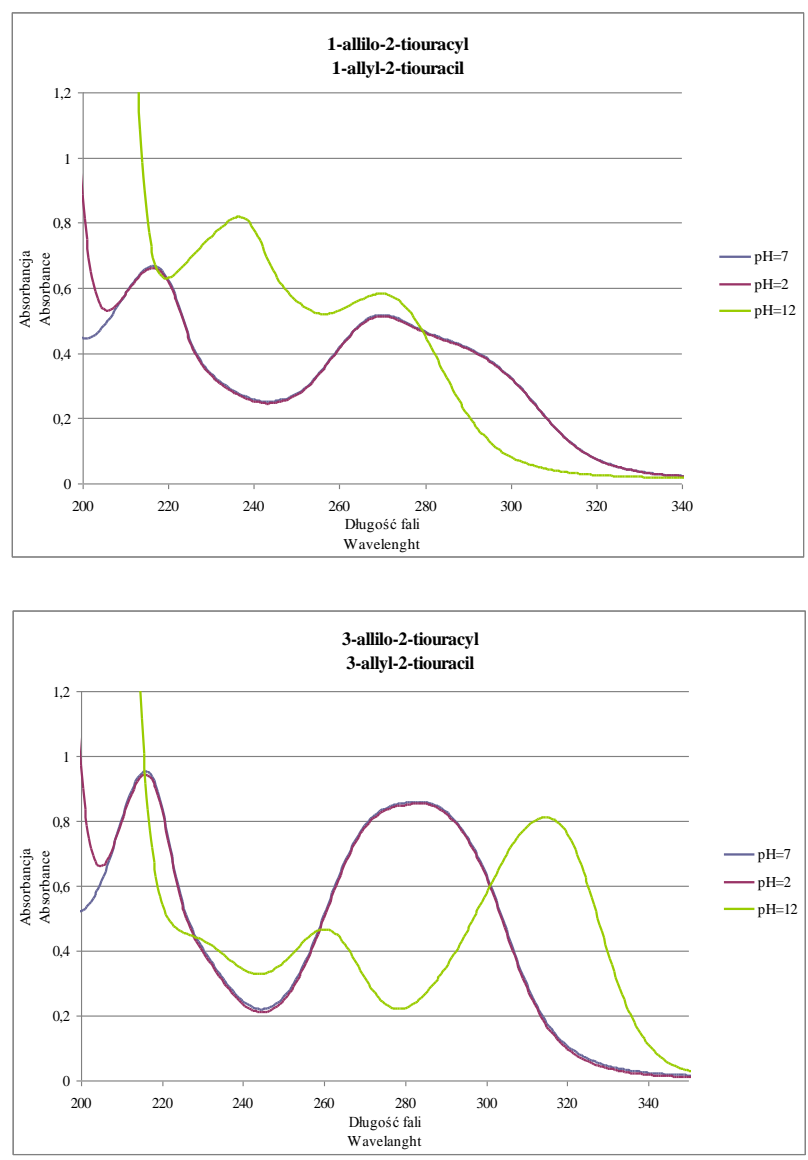

Fig. 1. The UV spectrum of 1-allyl-2-thiouracil and 3-allyl-2thiouracil

Rys. 1. Widmo UV 1-allilo-2-tiouracylu i 3-allilo-2-tiouracylu

The UV spectrum of 2-thiouracil derivatives completely confirmed the results obtained, which allows determination of the position of the rest of the allyl in pyrimidine ring.

The ${ }^{1} \mathrm{H}$ NMR spectra also in the case of 1-methyl(3) and 3-methyl-5-isopropyluracil (4) allows the identification of the position of the methyl substituent in the pyrimidine ring. However, information obtained from the ${ }^{1} \mathrm{H}$ NMR spectrum are poorer. This is due to the absence of a proton at position 5 .

The scheme 3 shows the structure and the chemical shifts of the protons of 1-methyl- and 3-methyl-5isopropyluracil.

In order to confirm the location of the substituent calculated coupling constants C-6 proton. The ${ }^{1} \mathrm{H}$ NMR spectra of $\mathbf{3}$ showing the doublet with the small coupling constant $\mathrm{J}_{\mathrm{C} 6 \text {-Ciso }}(0.9 \mathrm{~Hz})$. The proton $\mathrm{C}-6-\mathrm{H}$ in 1-methyl-5-isopropyluracil is coupled to one proton 
from isopropyl group with the small coupling constant $\mathrm{J}_{\text {C6-Ciso }}(0.9 \mathrm{~Hz})$. However, $\mathrm{C}-6-\mathrm{H}$ in the $N 3$ derivative is coupled to two protons. The $\mathrm{C}-6-\mathrm{H}$ is split for doublet of doublets with the long-range coupling constant $\mathrm{J}_{\mathrm{N} 1-\mathrm{C} 6} 5.7 \mathrm{~Hz}$ and the short-range coupling constant $\mathrm{J}_{\mathrm{C} 6 \text {-Ciso }} 0.9 \mathrm{~Hz}$. This additional coupling constant indicates the close location of the C-6- $\mathrm{H}$ and N1-H.

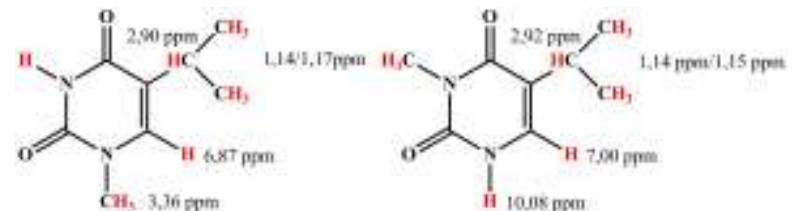

1-metylo-5-izuprepylearaci| 1-methi-s-soprepglurneil

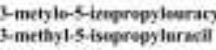

Scheme 3. The proton chemical shifts of 1-methyl-2isopropyluracil and 3-methyl-2-isopropyluracil

Schemat 3. Przesunięcia chemiczne protonów 1-metylo-5izopropylouracylu i 3-metylo-5-izopropylouracyl

As in case of 1- and 3-allyl derivatives of 2thiouracil interpretation of spectra ${ }^{1} \mathrm{H}$ NMR is used to confirm the structure of these molecules. The UV spectrum confirmed these results (Figure 2).
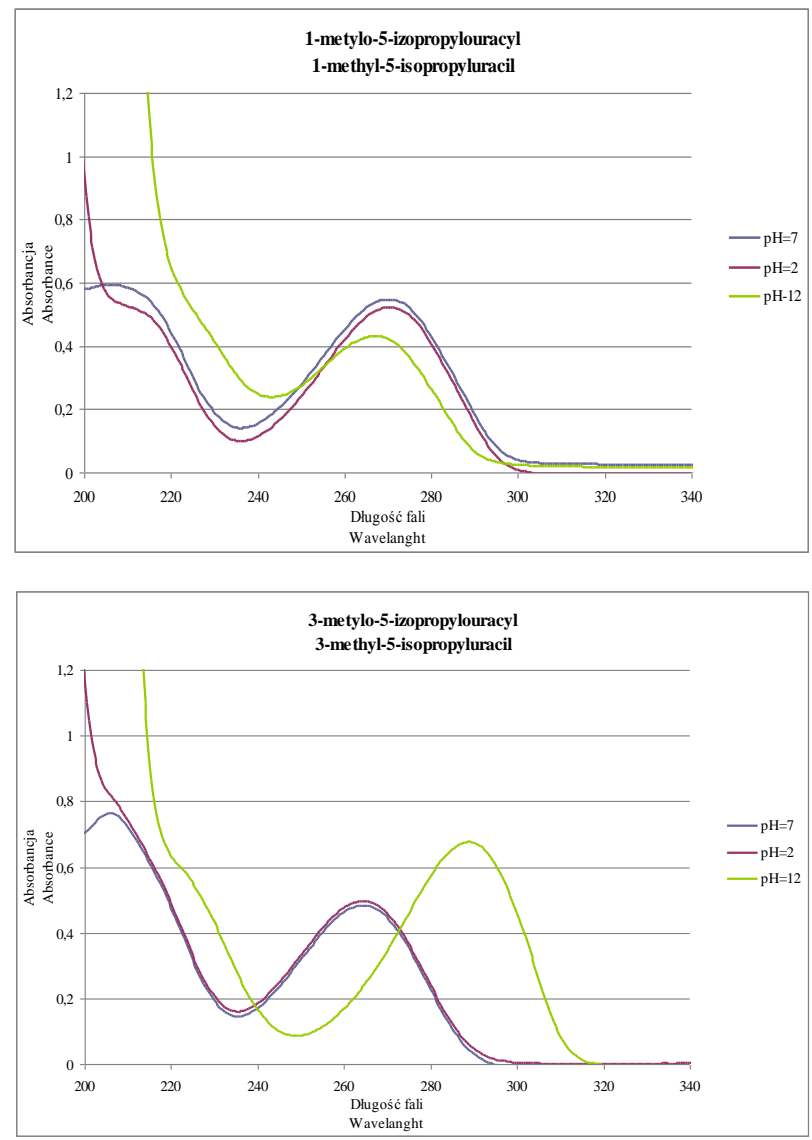

Fig. 2. The UV spectrum of 1-methyl-5-isopropyluracil and 3-methyl-5-isopropyluracil
Rys. 2. Widmo UV 1-metylo-5-izopropylouracylu i 3-metylo5-izopropylouracylu

The absorption spectrum of 1-methyl-5isopropyluracil at $\mathrm{pH} 12$ was shifted to shorter wavelengths (269 nm). However, 3-methyl-5isopropyluracil produced the significant bathochromic shift of the absorption maxima $\left(\Delta \lambda_{\max }=25 \mathrm{~nm}\right)$. In this simple way it can be stated clearly at which the nitrogen atom is a methyl substituent.

The situation is quite different in case of a series of 1- (5) and 3-allyl derivatives of 5.6-tetramethyleneuracil (6). The chemical shift values are given below (Scheme 4).
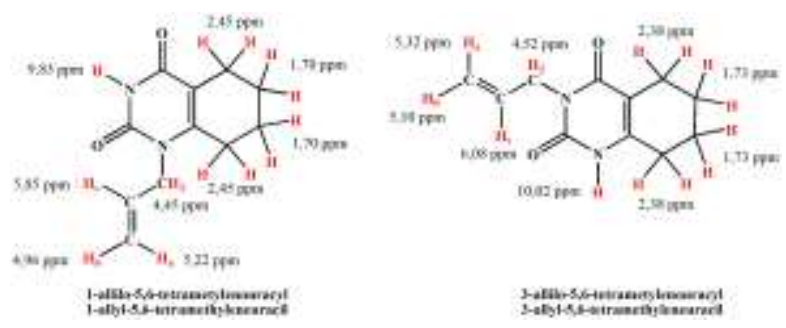

Scheme 4. The proton chemical shifts of 1-allyl-5,6tetramethyleneuracil and 3-allyl-5,6-tetramethyleneuracil

Schemat 4. Przesunięcia chemiczne protonów 1-allilo-5,6tetrametylenouracylu i 3-allilo-5,6-tetrametylenouracyl

In these compounds ( 5 and $\mathbf{6})$ there are no protons at C-5 and C-6. On the basis of the ${ }^{1} \mathrm{H}$ NMR spectrum cannot be concluded that the nitrogen atom is substituted. The ${ }^{1} \mathrm{H}$ NMR spectrum in this case, it becomes unhelpful. In this situation, the implementation of spectrophotometric analysis appears necessary (Figure 3).

As in previous cases, depending on the position of the allyl group in the pyrimidine ring is in the alkaline environment of the characteristic hypsochromic shift for 1-allyl-5,6-tetramethyleneuracil and the bathochromic shift for 3-allyl-5,6-tetramethyleneuracil.

In an alkaline conditions the absorption band was shifted to shorter wavelengths by about $2 \mathrm{~nm}$. At the same time reduction in the molar absorption coefficient was observed in this environment. In contrast, N3 derivative is visible in the spectrum of UV bathochromic shift (about $20 \mathrm{~nm}$ ) bands of long-term, high molar extinction coefficient. Only UV spectrum clearly confirm position of $N$-substituent. 

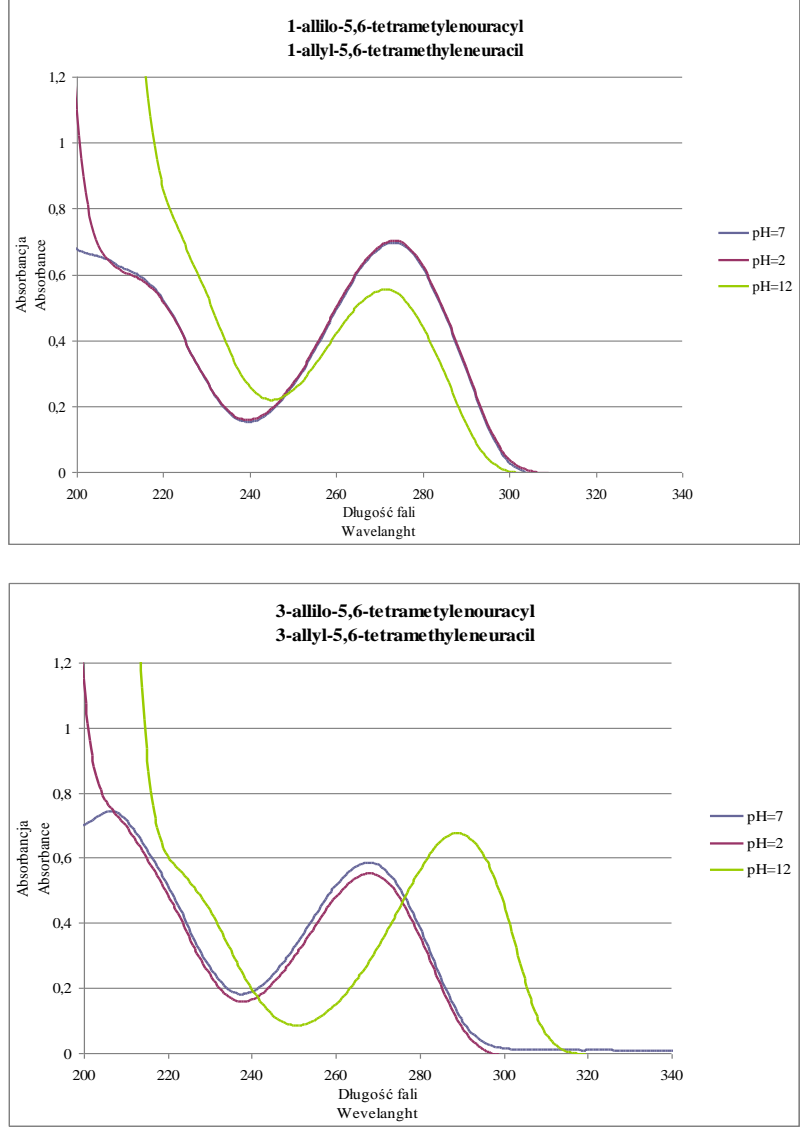

Fig. 3. The UV spectrum of 1-allyl-5,6-tetramethyleneuracil and 3-allyl-5,6-tetramethyleneuracil

Rys. 3. Widmo UV 1-allilo-5,6-tetrametylenouracylu i 3-allilo-5,6-tetrametylenouracylu

\section{CONCLUSION}

In the present work, we can conclude:

1. The ${ }^{1} \mathrm{H}$ NMR provides much more information about the structure of the compound; however, when pyrimidine ring does not have the protons C-5 and C-6, identification of isomers of $N 1$ and $N 3$ by NMR is not possible. Without performing spectrophotometric analysis knowledge about the structure of the compound would be incomplete. The UV spectra allows the identification of the substituent in the pyrimidine ring.

2. The absorption spectra in an alkaline medium for the various 1-substituted uracil showed that there is a general tendency for the absorption band to move hypsochromically.

3. The absorption spectra in an alkaline medium for the various 3-substituted uracil produced bathochromic shift.

\section{REFERENCES}

1. Gopalsamy A., Bennett E. M., Shi M., Identification of pyrimidine derivatives as hSMG-1 inhibitor, Bioorganic \& Medicinal Chemistry Letters, 2012, 22, 6636-6641.

2. Zhu W., Liu Y., Zhai X., Design, synthesis and 3DQSAR analysis of novel 2-hydrazinyl-4morpholinothieno[3,2-d]pyrimidine derivatives as potential antitumor agents, Eur. J. Med. Chem., 2012, 162-175.

3. Lukasik P. M., Elabar S., Lam F., Synthesis and biological evaluation of imidazo[4,5-b]pyridine and 4-heteroarylpyrimidine derivatives as anti-cancer agents, Eur. J. Med. Chem., 2012, 57, 311-322.

4. Kassab A. E., Gedawy E. M., Synthesis and anticancer activity of novel 2-pyridyl hexahyrocyclooctathieno[2,3d]pyrimidine derivatives, Eur. J. Med. Chem., 2013, 63, 224-230.

5. Coen N., Singh U., Vuyyuru V., Activity and mechanism of action of HDVD, a novel pyrimidine nucleoside derivative with high levels of selectivity and potency against gammaherpesviruses, Journal of Virology, 2013, 87, 3839-3851.

6. Abd El Hamid M. K., Mihovilovic M. D., El-Nassan H. B., Synthesis of novel pyrazolo[3,4-d]pyrimidine derivatives as potential anti-breast cancer agents, Eur. J. Med. Chem., 2012, 57, 323-328.

7. Zenker N., Thyroid function and thyroid drugs. In: Principles of Medicinal Chemistry. Foye W.O., Lea \& Febiger: Philadelphia, London, UK, 1990, 603-621.

8. Del Carmen Núñeza M., Entrena A., Rodríguez-Serrano F., Synthesis of novel 1-(2,3-dihydro-5H-4,1benzoxathiepin-3-yl)-uracil and -thymine, and their corresponding $S$-oxidized derivatives, Tetrahedron, 2005, 61, 10363-10369.

9. Prachayasittikul S., Sornsongkhram N., Pingaew R., Synthesis of $\mathrm{N}$-Substituted 5-iodouracils as antimicrobial and anticancer agents, Molecules, 2009, 14, 2768-2779.

10. Semenov V. E., Voloshina A. D., Toroptzova E. M., Antibacterial and antifungal activity of acyclic and macrocyclic uracil derivatives with quaternized nitrogen atoms in spacers, Eur. J. Med. Chem., 2006, 41, 1093 1101.

11. Maruyama T., Kozai S., Shimizu T., Synthesis and hypnotic-sedative activities of $\mathrm{N}$-substituted uracil on mice, Nucleic Acids Research Supplement, 2003, 3, 25-26.

12. Dramiński M., Frass E., Alkylated derivatives of uracile. Part IX. Synthesis of $N$-(2,3-dihydroxypropyl)derivatives of 5,6-tetramethyleneuracil, structutral analogs of nucleosides, Polish Journal of Chemistry, 1981, 15471552. 
13. Turski K., Nowe pochodne tiazolo[3, 2-a]pirymidyny potencjalne immunomodulatory, praca doktorska, Łódź, 1992.

14. Dramiński M., Fiszer B., Alkilowanie pochodnych uracylu. II. Synteza i właściwości $N$-metylowanych 5i 5,6-alkilowanych uracyli, Roczniki Chemii Ann. Soc. Chim. Polonorum., 1971, 45, 19-25
Address for correspondence:

Department of Biochemistry

Nicolaus Copernicus University in Torun

Collegium Medicum in Bydgoszcz

ul. Karłowicza 24

85-092 Bydgoszcz, Poland

phone: + 4852 585-37-55

fax: (52) 585-39-43

e-mail: renatak@cm.umk.pl

M. Stupała, E. Kopkowska, B. Augustyńska kizbioch@cm.umk.pl

Received: 17.03.2015

Accepted for publication: 10.11.2015 